\title{
NEW SPECIMENS OF MERYCOPOTAMUS (ARTIODACTYLA: ANTHRACOTHERIIDAE) FROM MIDDLE MIOCENE OF POTWAR PLATEAU, PAKISTAN
}

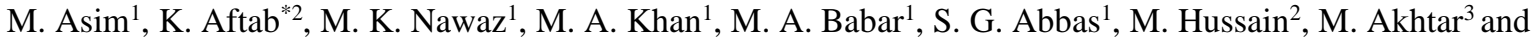 \\ A. M. Qureshi ${ }^{3}$ \\ ${ }^{1}$ Dr. Abu Bakr Fossil Display \& Research Centre, Department of Zoology, Quid-e-Azam Campus, University of the \\ Punjab, Lahore 54590, Pakistan \\ ${ }^{2}$ Department of Zoology, University of Gujrat, Gujrat, Punjab, Pakistan, \\ ${ }^{3}$ School of Zoology, Minhaj University Lahore, Pakistan \\ Corresponding author's email: dr.kiran@uog.edu.pk
}

\begin{abstract}
The Merycopotamus remains are described from the Chinji Formation (middle Miocene) of the Lower Siwalik Subgroup of Pakistan. The material recovered from two fossiliferous localities of Chabbar Syedan and Dhok Bun Ameer Khatoon in Chakwal district, Punjab, Pakistan. The described specimens of Merycopotamus nanus add additional knowledge on Pakistani anthracotheriid diversity.
\end{abstract}

Keywords: Artiodactyls, Anthracotheriids, Merycopotamus, Chinji Formation, middle Miocene.

\section{INTRODUCTION}

The Potwar Plateau is the most fertile area in the Siwaliks that represents the extensive record of the vertebrate fossils (Pilbeam et al., 1979; Badgley et al., 2008; West et al., 2010). Anthracotheriidae was very diversified in this region during Neogene (Pilgrim, 1913; Forster-Cooper, 1924; Black, 1978; Gaziry, 1987; Pickford, 1987). The described specimens of Merycopotamus are collected from two different localities of the Chinji Formation: Chabbar Syedan and Dhok Bun Ameer Khatoon. Both the sites have yielded many mammalians remains that belong to the middle Miocene age. The newly found specimens document the poorly known anthracotheriid group from the Siwalik Group.

Chabbar Syedan: The studied outcrops (Lat. $33^{\circ}$ 00'16.1' N; Long. 73 ${ }^{\circ} 13^{\prime} 29.0^{\prime \prime}$ E) are present nearby the Chabbar Syedan village, district Jhelum, Punjab, Pakistan (Fig. 1). The Formation is dominant in this area as the red claystone placed on subordinate hard grey sandstone with interbedding narrow beds of siliceous nodules (Aftab et al., 2015, 2019; Abbas et al., 2016). Chabbar Syedan denotes the middle stage of the Chinji Formation with approximate age of 13.2-12.2 Ma (Barry et al., 2002; Nanda, 2002, 2008).

Dhok Bun Ameer Khatoon: The outcrops (Lat. $32^{\circ} 47^{\prime} \mathrm{N}$; Long. $72^{\circ} 55^{\prime} \mathrm{E}$ ) are located in the northeast of Choa Saidan Shah, Chakwal, Punjab, Pakistan (Fig. 1). The outcrops contain sandstones, siltstones and shales dumped in a riverine environment, mostly packed by uneroded igneous mineral sediments (Cheema, 2003;
Khan et al., 2008, 2011). Dhok Bun Ameer Khatoon denotes the lower stage of Chinji Formation with age of almost 14.2-13.2 Ma (Barry et al., 2002; Nanda, 2002, 2008).

\section{MATERIALS AND METHODS}

The material was collected from the middle Miocene localities of the Potwar Plateau, Northern Pakistan (Fig. 1). The specimens, collected from the surface, were transported to the laboratory and prepared for the taxonomic study. The specimens were catalogued, and their length and width (in $\mathrm{mm}$ ) measured at occlusal level by a digital caliper. The dental terminology and measurements follow Lihoreau (2003). The fossils are kept in Dr. Abu Bakr Fossil Display and Research Centre, Department of Zoology, University of the Punjab, Lahore, Pakistan.

Abbreviations: BMNH-British Museum of Natural History; PUPC-Punjab University Paleontological Collection, University of the Punjab, Lahore, Pakistan; 1left; r-right; p-lower premolar; m-lower molar; M-upper molar, Ma-million years ago.

Systematic Palaeontology: Family Anthracotheriidae Leidy, 1869

Genus MERYCOPOTAMUS Falconer and Cautley, 1847

Merycopotamus nanus Falconer, 1868

Holotype: BMNH, M40766, right M1 (Falconer, 1868). 
Type locality: Khushalgarh, below Attock, the Punjab province, Pakistan (Falconer, 1868).

Diagnosis: As described by Lihoreau et al. (2007).

Stratigraphic level: Chinji Formation - middle Miocene (Falconer, 1868; Lihoreau et al., 2007).

New material: PUPC 17/232, rp3 (Dhok Bun Ameer Khatoon); PUPC 18/251, lp3 (Chabbar Syedan); PUPC 15/440, lm1 (Dhok Bun Ameer Khatoon); PUPC 16/209, $\operatorname{lm} 3$ (Chabbar Syedan).

Description and comparison: PUPC $17 / 232$ is a rp3 having coarse enamel and is triangular in shape (Fig. $2(1)$ ). The anterior valley is broad and open. The anterior lobe includes the protoconid and paraconid, whereas the hypoconid covers most of the tooth posteriorly. A large cingulid covers the base of the tooth.

PUPC $18 / 251$ is a well-worn and fragile lp3 (Fig. 2(2)), that preserves the hypoconid and entoconid only partially. The base of the tooth is completely covered by a thick cingulum throughout its length. The metaconid is higher than all the other conids. The roots are well preserved and the enamel is highly wrinkled.

PUPC $15 / 440$ is a well-worn $\operatorname{lm} 1$ (Fig. 2(3)), in which the protoconid, hypoconid, and entoconid are partially broken. The mesostylid is preserved. The median valley is partially closed by a small tubercle. A thick cingulid is preserved at the base of the postprotocristid. The roots are well preserved.
PUPC 16/209 is mandibular fragment with $\operatorname{lm} 3$ (Fig. 2(4)). The preserved portion of the corpus is extremely weathered, fragile and cracked at various places. The anterior and posterior valleys show small tubercles. A thick cingulum is present at the base of the preprotocristid. The hypoconulid is massive and has a tubercle at its lingual side. A small cingulum is covered base of the hypoconulid.

The characteristics of this material is also the presence of an additional cusp on the mesiolingual apex of the premolars, the lack of premetacristid in the molar, access of prehypocristid and preentocristid to the lingual border of the molar and the position of the hypoconulid, in line with buccal cusps. All these characters belong to Merycopotamus (Lihoreau et al., 2007). The Siwalik Merycopotamus is represented by three species: $M$. nanus, M. medioximus and M. dissimilis (Falconer, 1868; Falconer and Cautley, 1836, 1847; Lihoreau et al., 2004). Merycopotamus nanus is different from M. medioximus by the smaller size of the lower molars (Fig. 3). It differs from the teeth of $M$. dissimilis by lacking the entoconid fold and by having loop-like hypoconulid in the $\mathrm{m} 3$ (Lihoreau et al., 2007). The size of the described material clearly documents a species smaller than $M$. medioximus and $M$. dissimilis, their size falling within the range of $M$. nanus (Fig. 2, 3; Table 1). Furthermore, also the described lower molars present the occlusal pattern of $M$. nanus (Lihoreau et al., 2007).

Table 1. The teeth measurements (in $\mathrm{mm}$ ) of Merycopotamus. * represents the specimens described in the present study. Comparative material from Lihoreau et al. (2007), and Khan et al. (2013).

\begin{tabular}{|c|c|c|c|c|c|}
\hline Taxa & Inventory No. & Nature \& Position & Length & Width & W/L \\
\hline \multirow{8}{*}{ M. nanus } & PUPC17/232* & $\mathrm{rp3}$ & 14.52 & 10.10 & 0.70 \\
\hline & PUPC $18 / 251^{*}$ & lp3 & 16.5 & 12.0 & 0.73 \\
\hline & PUPC 15/440* & $\operatorname{lm} 1$ & 15.00 & 11.24 & 0.75 \\
\hline & PUPC16/209* & $\operatorname{lm} 3$ & 30.0 & 15.5 & 0.52 \\
\hline & & p3 & 15.7 & 10.1 & 0.68 \\
\hline & Lihoreau et al., 2007 (average values) & $\mathrm{m} 1$ & 19.7 & 12.4 & 0.63 \\
\hline & & $\mathrm{m} 3$ & 33.2 & 15.9 & 0.48 \\
\hline & PUPC 13/5 & $\mathrm{rm} 3$ & 32.0 & 16.0 & 0.50 \\
\hline \multirow{3}{*}{ M. dissimilis } & & p3 & 18.0 & 10.0 & 0.56 \\
\hline & Lihoreau et al., 2007 (average values) & $\mathrm{m} 1$ & 20.7 & 14.0 & 0.68 \\
\hline & & $\mathrm{m} 3$ & 39.2 & 20.1 & 0.51 \\
\hline \multirow{3}{*}{ M. medioximus } & CCZ234 & p3 & 21.2 & 13.5 & 0.64 \\
\hline & CCZ234 & $\mathrm{m} 1$ & 21.7 & 14.6 & 0.67 \\
\hline & CCZ233 & $\mathrm{m} 3$ & 40.7 & 19.5 & 0.48 \\
\hline
\end{tabular}

\section{DISCUSSION}

Merycopotamus was documented from the Siwalik Hills of the Indian Subcontinent (Falconer and Cautley, 1836, 1847; Falconer, 1868; Colbert, 1938, 1943), as well as from Iraq (Brunet and Heintz, 1983),
Nepal (Munthe et al., 1983), Indonesia (Königswald, 1933) and Thailand (Hanta et al., 2005, 2008). In the Siwaliks, this genus was first described and discussed in detail by Falconer and Cautley (1847). Merycopotamus was recorded from the Chinji to Dhok Pathan formations of the Siwalik succession in the Potwar Plateau, Pakistan (Pilbeam et al., 1977, 1979). The chronologically 


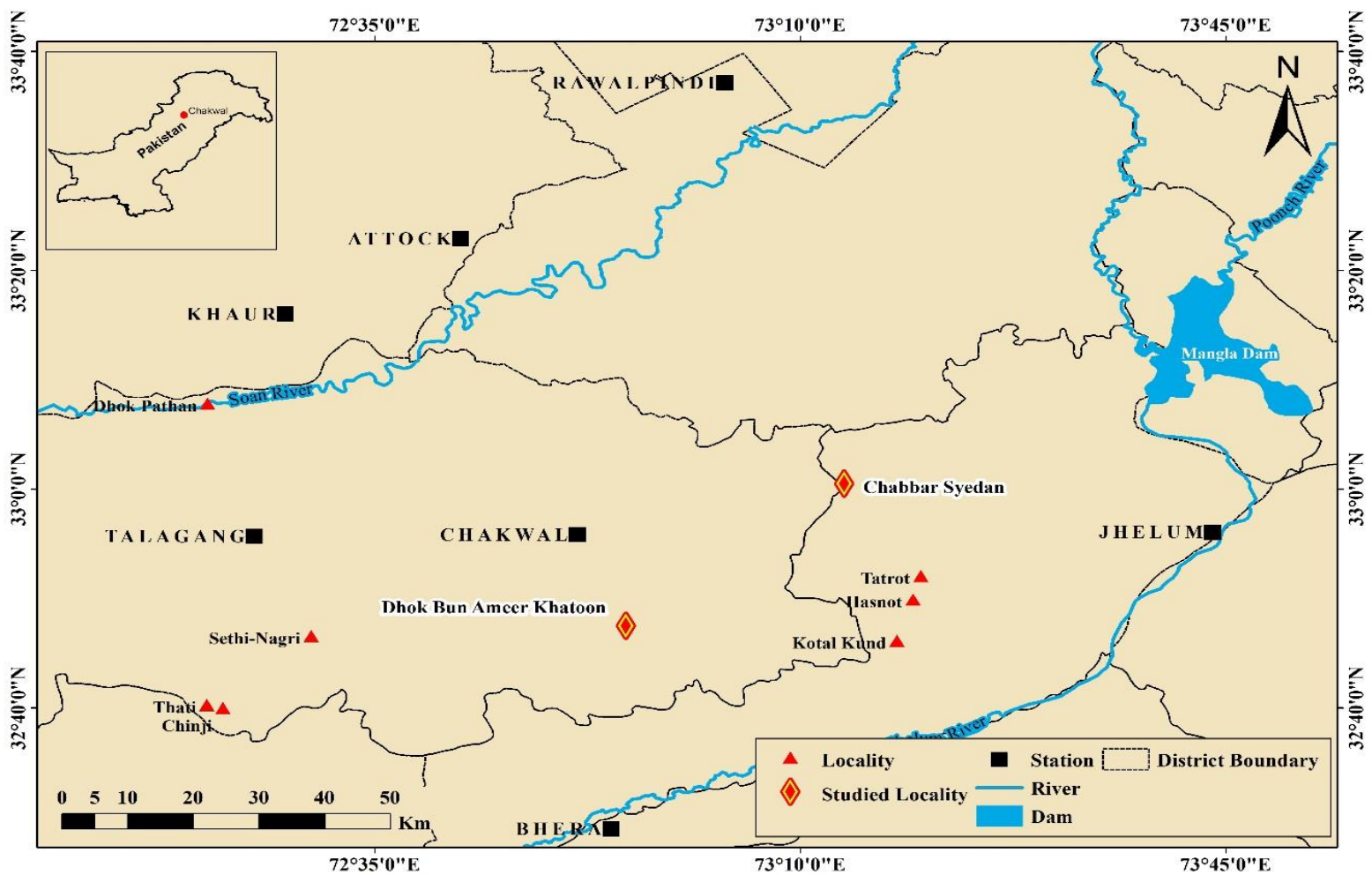

Fig. 1. Map of Potwar Plateau in Pakistan showing the localities that yielded the specimens described in this paper.
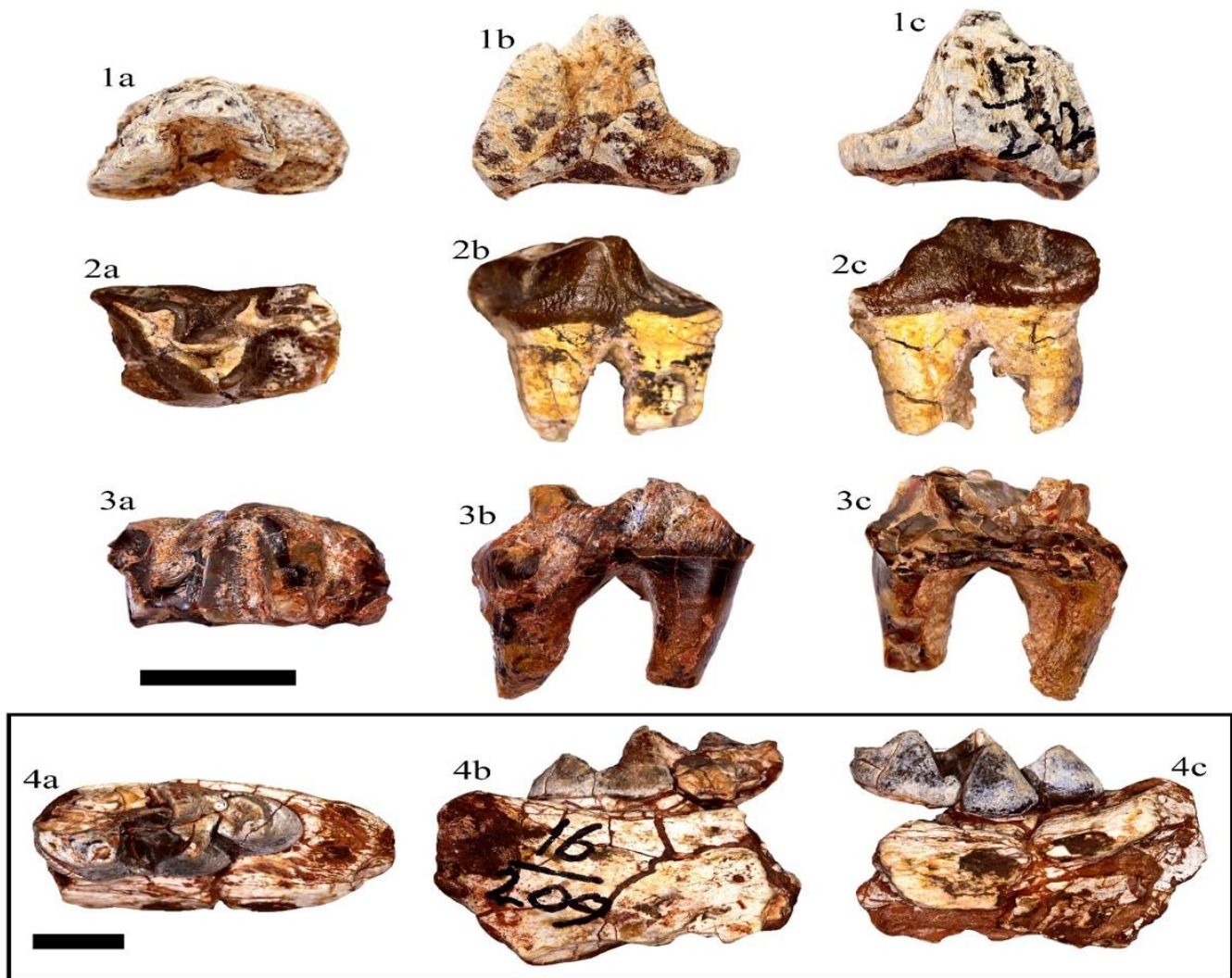

Fig. 2. Merycopotamus nanus. Lower dentition: 1. PUPC 17/232, rp3; 2. PUPC 18/251, Ip3; 3. PUPC 15/440, $\operatorname{lm1}$; 4. PUPC 16/209, Im3. Views: a) occlusal, b) lingual, c) labial. Scale bar $10 \mathrm{~mm}$. 

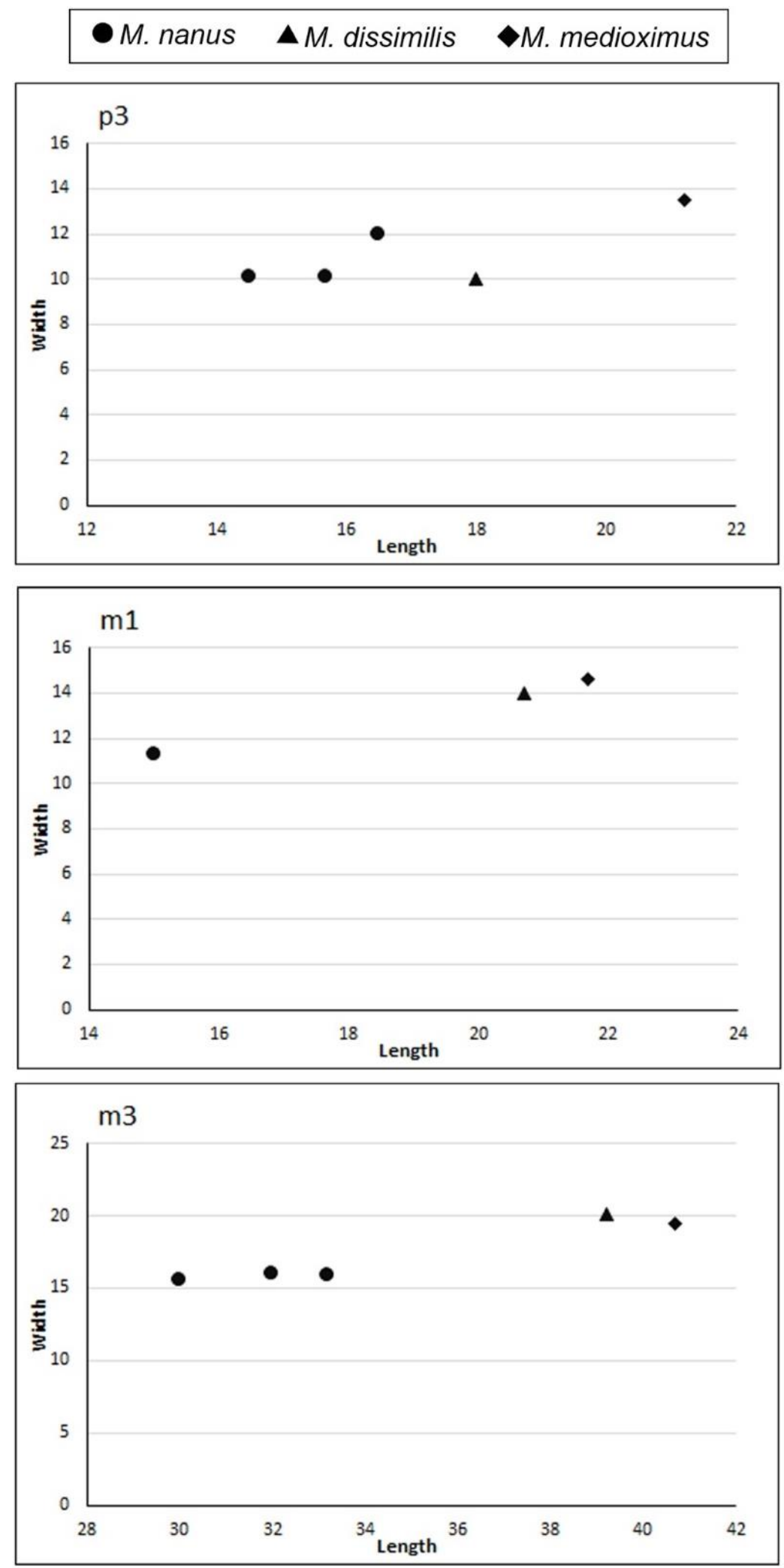

Fig. 3. Scatter diagrams showing dental proportions of Merycopotamus. Comparative material from Lihoreau $e t$ al. (2007) and Khan et al. (2013). 


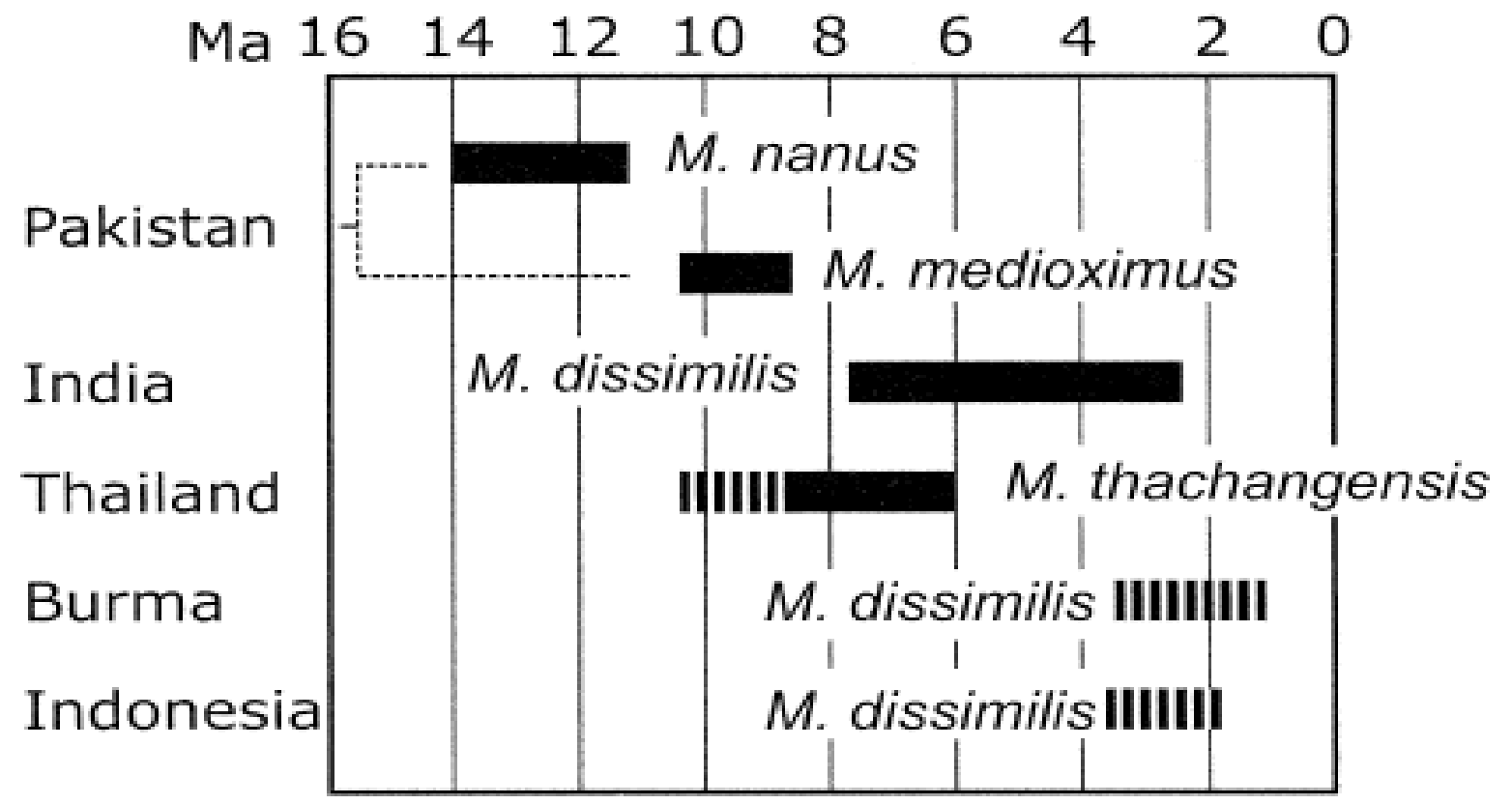

Fig. 4. Temporal distribution of Merycopotamus from various Miocene to early Pleistocene localities of Asia, including Pakistan (taken from Hanta et al., 2008).

youngest Merycopotamus in this region was found from Azad Kashmir (2.6-2.4 Ma; Steensma and Hussain, 1992). Temporally, the genus ranges from the middle Miocene to early Pleistocene of the Siwalik Group (Steensma and Hussain, 1992; Barry et al., 2002; Lihoreau et al., 2007). The Tatrot Formation yielded two species of Merycopotamus i.e. M. minor and M. major, both species being renamed as $M$. nanus by Falconer (1868) and $M$. dissimilis by Falconer and Cautley (1847) respectively. Later, Colbert (1935) synonymized $M$. nanus with $M$. dissimilis. Lihoreau (2003) studied the Merycopotamus specimens collected by the team of the Geological Survey of Pakistan and the Peabody Museum of Yale University, then he established a new additional species, M. medioximus (Lihoreau et al., 2004).

M. nanus (basal species) was found in the Chinji Formation (13.9-11.3 Ma, middle Miocene) of the Siwalik Group (Pilbeam et al., 1977, 1979; Barry et al., 2002, Lihoreau, 2003; Hanta et al., 2008). M. medioximus (slightly derived), described by Lihoreau et al., (2004), is an intermediate form. It was found in the Nagri and lower Dhok Pathan formations (10.4-8.6 Ma, early Late Miocene) of the Siwalik Group (Lihoreau et al., 2004). M. dissimilis (derived form) is the youngest species and present in the upper Dhok Pathan, Tatrot, and lower Pinjor formations (7.8-2.4 Ma, late Miocene to early Pleistocene) of the Siwalik Group (Barry et al., 2002; Lihoreau et al., 2007).

$M$. medioximus and $M$. dissimilis share a synapomorphic character (the mesostyle division) which clearly reflects that $M$. nanus is a stem group of the genus. $M$. nanus is confined to the Indian subcontinent and is the oldest representative in the middle Miocene of Lower Siwalik Subgroup (Chinji Formation) (Fig. 4). If the morphology (division) of the mesostyle is regarded as the important character in Merycopotamus evolution, it is considered that $M$. medioximus (early Late Miocene) is the first slightly more derived species emigrated from Indian Subcontinent to Thailand and developed into a new form, Tha Chang Merycopotamus (Lihoreau et al., 2007; Hanta et al., 2008).

Conclusions: A rare species, M. nanus is reported from the outcrops of Potwar Plateau, Pakistan, based on additional specimens discovered recently. This material adds to the lower dentition of middle Miocene age of the Siwalik Group referred to $M$. nanus. The localities Chabbar Syedan and Dhok Bun Ameer Khatoon correspond to the upper part of the middle Miocene of the Siwalik Group, thus confirming the first appearance of $M$. nanus in the subcontinent.

\section{REFERENCES}

Abbas, S.G., M.A. Khan, M.A. Babar, R. Shahid, M.K. Nawaz, and M. Akhtar (2016). Some new fossils of Protanancus chinjiensis (Proboscidea, Mammalia) from middle Miocene of Pakistan. Biologia (Pakistan), 62: 345-349.

Aftab, K., M. Asim, M.K. Nawaz, M.A. Babar, M.A. Khan, and Z. Ahmad (2019). New Giraffokeryx and Giraffa (Ruminantia, Giraffidae) dental 
material from Lower Siwalik of Northern Pakistan. Pakistan J. Zool. 51(1): 177-188.

Aftab, K., Z. Ahmad, M.A. Khan, and M. Akhtar (2015). Additional Giraffokeryx remains (Artiodactyla: Ruminantia: Giraffidae) from the Chinji Formation of Lower Siwaliks, Northern Pakistan. Pakistan J. Zool. 47(5): 1393-1403.

Badgley, C., J.C. Barry, M.E. Morgan, S.V. Nelson, A.K. Behrensmeyer, and T.E. Cerling (2008). Ecological changes in Miocene mammalian record show impact of prolonged climatic forcing. PNAS USA. 105: 12145-12149.

Barry, J.C., M.E. Morgan, L.J. Flynn, D. Pilbeam, A.K. Behrensmeyer, S.M. Raza, I.A. Khan, C. Badgley, J. Hicks, and J. Kelley (2002). Faunal and environmental change in the late Miocene Siwaliks of northern Pakistan. Paleob. 28(2): 171.

Black, C.C. (1978). Anthracotheriidae. In: Evolution of African mammals (Eds., V.J. Maglio, and H.B.S. Cooke) Harvard University Press Cambridge, pp. 423-434.

Brunet, M. and E. Heintz (1983). Interpretation paleoecologique at relations biogeographiques de la faune de vertebrees du Miocene Superieur D'Injana, Irak. Palaeogeogr. Palaeoclimatol. Palaeoecol. 44: 283-293.

Cheema, I.U. (2003). Phylogeny and evolution of Neogene murine rodents from the Potwar Plateau of Pakistan and Azad Kashmir with special emphasis on zoogeographic diversification and stratigraphic implications. Ph.D. thesis (unpublished). University of the Punjab, Lahore, Pakistan.

Colbert, E.H. (1935). Siwalik mammals in the American Museum of Natural History. Trans. Am. Phil. Soc. 26: 1-401.

Colbert, E.H. (1938). Fossil mammals from Burma in the American Museum of Natural History. Bull. Am. Mus. Nat. Hist. 74: 255-436.

Colbert, E.H. (1943). Pleistocene vertebrates collected in Burma by the American Southeast Asiatic Expedition. Trans. Am. Phil. 32 (3): 395-429.

Falconer, H. (1868). Paleontological memoirs and notes, London. 1: 1-590.

Falconer, H. and P.T. Cautley (1836). Note of the fossil camel on the Siválik Hills. Asi. Res. 19: 115134.

Falconer, H. and P.T. Cautley (1847). Fauna Antiqua Sivalensis Pt. 8: 69-71.

Forster-Cooper, C. (1924). The Anthracotheriidae of the Dera Bugti deposits in Baluchistan. Palaeontol. Ind. 8(2): 1-77.

Gaziry, A.W. (1987). Merycopotamus petrocchii (Artiodactyla, Mammalia) from Sahabi, Libya. In: Neogene paleontology and geology of Sahabi
(Eds., A.B. El-Arnauti, A.W. Gaziry, J.D. Heinzelin, and D. Boaz) Allan Liss. New York, pp. 287-302.

Hanta, R., B. Ratanasthien, Y. Kunimatsu, H. Saegusa, H. Nakaya, and P. Jintasakul (2005). Description of the Tha Chang Merycopotamus and its preserved condition. In: Proceedings of the International Conference on Geology, Geotechnology and Mineral Resources of Indochina, Khon Kean, Thailand (Eds., L. Wannakao, K. Srisuk, W. Youngme, and R. Lertsirivorakol) Khon Kean, Thailand, pp. 600-605.

Hanta, R., B. Ratanasthien, Y. Kunimatsu, H. Saegusa, H. Nakaya, S. Nagaoka, and P. Jintasakul (2008). A new species of Bothriodontinae, Merycopotamus thachangensis (Cetartiodactyla, Anthracotheriidae) from the late Miocene of Nakhon Ratchasima, northeastern Thailand. J. Vertebr. Paleontol. 28(4): 1182-1188.

Khan, M.A., M. Akhtar, A. Ghaffar, M. Iqbal, A.M. Khan, and U. Farooq (2008). Early Ruminants from Dhok Bin Mir Khatoon (Chakwal, Punjab, Pakistan): Systematics, biostratigraphy and paleoecology. Pakistan J. Zool. 40(6): 457-463.

Khan, M.A., M. Akhtar, A.M. Khan, A. Ghaffar, M. Iqbal, and K. Samiullah (2011). New fossil locality in the middle Miocene of Lava from the Chinji Formation of the Lower Siwaliks. Pakistan J. Zool. 43: 61-72.

Khan, M.A., M. Akhtar, M.A. Babar, S.G. Abbas, M.K. Siddiq, M.K. Nawaz, M. Mubasar, H. Yaqoob, S. Nazir, S. Farheen, O. Draz, S. Shahbaz, N. Sultana, N. Zahra, and S. Noreen (2013). Some new remains of middle Miocene mammals from the Chinji Formation, northern Pakistan. Pakistan J. Zool. 13(Suppl): 1-55.

Konigswald, V.G.H.R. (1933). Beitrag zur Kenntnis der fossilen saugetier fauna Javas. Wetenschappelijke Mededelingen Dienst van den Mijnbouw in Nederlandsch-Indië 23: 1-185.

Lihoreau, F. (2003). Systématique et paléoécologie des Anthracotheriidae [Artiodactyla; Suiformes] du Mio-Pliocène de l'Ancien Monde: implications paléobiogéographiques. Ph.D. dissertation, Universite de Poitiers, Poitiers, France.

Lihoreau, F., C. Blondel, J. Barry, and M. Brunet (2004). A new species of the genus Microbunodon (Anthracotheriidae, Artiodactyla) from the Miocene of Pakistan: genus revision, phylogenetic relationships and palaeobiogeography. Zool. Scripta. 33: 97-115.

Lihoreau, F., J. Barry, C. Blondel, Y. Chaimanee, J.-J. Jaeger, and M. Brunet (2007). Anatomical revision of the genus Merycopotamus (Artiodactyla; Anthracotheriidae): its 
significance for late Miocene mammal dispersal in Asia. J. Palaeontol. 50(2): 503-524.

Munthe, J., B. Dongol, J.H. Hutchison, W.F. Kean, K. Munthe, and R.M. West (1983). New fossil discoveries from the Miocene of Nepal include a hominoid. Nature. 303: 331-333.

Nanda, A.C. (2002). Upper Siwalik mammalian faunas of India and associated events. J. Asian Earth Sci. 21: 47-58.

Nanda, A.C. (2008). Comments on the Pinjor mammalian fauna of the Siwalik Group in relation to the post-Siwalik faunas of Peninsular India and Indo-Gangetic plain. Quat. Int. 192: 6-13.

Pickford, M. (1987). Révision des suiformes (Artiodactyla, Mammalia) de Bugti (Pakistan). Ann. Paleontol. 73: 289-350.

Pilbeam, D., J. Barry, G.E. Meyer, S.M.I. Shah, M.H.L. Pickford, W.W. Bishop, H. Thomas, and L.L.
Jacobs (1977). Geology and palaeontology of Neogene strata of Pakistan. Nature. 270: 684689.

Pilbeam, D.R., A.K. Behrensmeyer, J.C. Barry, and S.M.I. Shah (1979). Miocene sediments and faunas of Pakistan. Postilla. 179: 1-45.

Pilgrim, G.E. (1913). Correlation of the Siwaliks with mammal horizons of Europe. Rec. GSI. 43(4): 264-326.

Steensma, K.J. and S.T. Hussain (1992). Merycopotamus dissimilis (Artiodactyla, Mammalia) from the Upper Siwalik Subgroup and its affinities with Asian and African Forms. Proc. K. Ned. Akad. Wet. C. 95(1): 97-108.

West, R.M., J.H. Hutchison, and J. Munthe (2010). Miocene vertebrates from the Siwalik Group, Western Nepal. J. Vertebr. Paleontol. 11(1): 108-129. 